\title{
Protease of Stenotrophomonas sp. from Indonesian fermented food: gene cloning and analysis
}

\author{
Frans Kurnia, ${ }^{1,2}$ Raymond R. Tjandrawinata, ${ }^{1}$ Adi Yulandi, ${ }^{2}$ Maggy T. Suhartono ${ }^{3}$ \\ ${ }^{1}$ Dexa Laboratories of Biomolecular Sciences, Dexa Medica, Cikarang; ${ }^{2}$ Faculty of Biotechnology, Atmajaya Catholic \\ University, Jakarta; ${ }^{3}$ Department of Food Science and Technology, Bogor Agricultural University, Bogor, Indonesia
}

\begin{abstract}
Screening of proteolytic and fibrinolytic bacteria from Indonesian soy bean based fermented food Oncom revealed several potential isolates. Based on 16s rDNA gene analysis, one particular isolate with the highest proteolytic and fibrinolytic activity was identified as Stenotrophomonas sp. The protease gene was
\end{abstract}

Correspondence: Maggy T. Suhartono, Department of Food Science and Technology, Bogor Agricultural University, Darmaga Campus PO.BOX 220. Bogor 16002, Indonesia.

Tel.: +62.8121115542- Fax: +62.251 .8626725$

E-mail: mthenawidjaja@yahoo.com

Key words: Protease gene; Stenotrophomonas sp.; indonesian fermented food Oncom; serine protease.

Contributions: FK: conducting experiment: gene cloning and analysis; RRT: planning methodology and helped discussion on the results, in particular with the protein structure; AY: involved in bioinformatic analysis; MTS: principal investigator, responsible for overall discussion and writing the manuscript.

Conflict of interest: the authors declare no potential conflict of interest.

Funding: this work was partly supported by research grant for Biotech Graduate Students of Atma Jaya Catholic University under principal investigator Professor Maggy Thenawidjaja Suhartono, and Dexa Laboratory of Biomolecular Sciences. Isolation and screening of the proteolytic and fibrinolytic bacteria was conducted at the Department of Food Science and Technology Bogor Agricultural University.

Acknowledgments: the authors thank Wangsa T. Ismaya, Ph.D of DLBS Dexa Medica for helpful discussion and Destya Hapsari Saputri, S.Si for technical support in this study. The Oncom isolate were collections of Diana Nur Afifah under supervision of Maggy Thenawidjaja Suhartono of Bogor Agricultural University.

Received for publication: 9 December 2016.

Revision received: 19 May 2017.

Accepted for publication: 3 June 2017.

CCopyright F. Kurnia et al., 2017

Licensee PAGEPress, Italy

Journal of Biological Research 2017; 90:6428

doi:10.4081/jbr.2017.6428

This article is distributed under the terms of the Creative Commons Attribution Noncommercial License (by-nc 4.0) which permits any noncommercial use, distribution, and reproduction in any medium, provided the original author(s) and source are credited. amplified to generate a 1749 bp Polymerase Chain Reaction product and BLAST analysis, revealed 90\% homology with gene encoding protease enzyme from Stenotrophomonas maltophilia. The putative amino acid sequence indicated a serine protease enzyme with typical amino acid aspartate, histidine and serine in the catalytic triad. The gene was translated into a pre-pro-protein consisted of cleavage site on its $\mathrm{N}$ terminal and Pre-Peptidase Cterminal domain. Cloning of the protease gene in pET22b with Escherichia coli BL21 DE3 as the host showed that the gene was expressed as insoluble protein fraction. This is the first report for analysis of protease gene from food origin Stenotrophomonas sp.

\section{Introduction}

Stenotrophomonas is a gram-negative bacteria; the genus compromises of eight species, ranging from common soil inhabitants to opportunistic human pathogens. Stenotrophomonas can be found throughout the environment, especially on plants. Among these species, full genome of Stenotrophomonas maltophilia had been reported. ${ }^{1} S$. maltophilia is catalase-positive, oxidase-negative (which distinguishes it from most other members of the genus). S. maltophilia is ubiquitous in aqueous environments, soil, and plants. This gram negative bacteria has become important for biotechnological application in agricultural and bioremediation due their ability to produce hydrolytic enzymes such as chitinase, glucanases, lipases, laccases and proteases., ${ }^{1,2}$ Extracellular protease from Stenotrophomonas sp is already used for biocontrol activity, such as for enhancing suppression of phytopathogenic fungi and virulence factor against giant parasitic nematode. ${ }^{3}$

Protease which catalyze cleavage of peptide bonds in proteins have important role in biochemical investigation, medical and industrial applications. Among the protease enzymes, serine protease is the major protease that has been widely used in technical enzyme applications, such as in leather, food and chemical industries and processes. ${ }^{4,5}$ This group of enzyme is excreted by various microorganisms and eukaryote. Some of the commercial serine proteases are subtilisin Carlsberg, subtilisin BPN and Savinase, with their major applications as detergent enzymes. ${ }^{6}$ Other serine proteases of medical interest/ applications are urokinase-type from human urine, streptokinase from Streptococci $s p$. and lumbrokinase from earthworms and several microorganisms. ${ }^{7,8}$

Despite numerous commercial proteases available, discovery of novel/unique protease is still being pursued due to demand of novelty, safer, higher activity and less expensive protease for industries and medical applications. ${ }^{4,5,9}$ Alkaline extracellular protease potential for detergent aplication from Stenophomonas maltophilia isolated from soil and medical samples had been reported. ${ }^{10,11}$ 
Interesting sources of proteases regarded as safe include some microorganism present in the traditional fermented food. Kim et al. screened proteolytic microorganism from Chungkook-Jang, a traditional Korean fermented-soybean sauce, with its activity about eight time higher than subtilisin Carlsberg. ${ }^{12}$ Protease with higher activity than plasmin known as anti-thrombosis agent was successfully screened by Uesugi et al. from the Japanese natto. ${ }^{13}$

Screening of proteolytic bacteria from Oncom as one of the traditional Indonesian fermented soy bean based product, revealed several potential isolates, namely Bacillus sp., Bacillus cereus and Stenotrophomonas sp. as confirmed by $16 \mathrm{srDNA}$ gene analysis Stenotrophomonas sp. was selected for further study and characterization due to its highest proteolytic activity among other isolates. This was shown through several quantitative parameters such as protease activity assay, fibrin plate assay and fibrin activity assay, which revealed that at similar protein concentration $(40 \mathrm{mg} / \mathrm{mL})$ the enzyme activity was similar to that of the commercial lumbrokinase, a fibrin degrading enzyme of the earthworm. ${ }^{14}$ The protease enzyme excreted by Stenotrophomonas sp. from fermented food Oncom was found as safe, as shown in the cell culture assay and animal experiments. ${ }^{15}$ The enzyme had been purified and found unique. ${ }^{14}$ This extracellular protease was the focus of our genomic and bioinformatic studies.

The structural genes encoding extracellular protease from $S$. maltophilia R551-3 (GenBank acession number CP001111) revealed five genes: StmPr1, StmPr2, StmPr3 and StmPr4 as well as an ATP-dependent metalloprotease FtsH. These serine proteases gene were composed of signal peptide, pro-peptide I, mature protease, and the C-terminal domain The actice site region revealed considerable homology with other serine protease family such as subtilisin, with the typical catalytic triad Asp, His, and Ser in the primary sequence. StmPr1-StmPr3 from S. maltophilia strain 19580 have a multi-domain structure including a signal peptide for translocation, a pro-peptide for maturation, the mature peptide and a C-terminal domain. Upon translation, all the domain was translated as proenzyme which later on processed into its mature form. ${ }^{16}$

In this manuscript we reported analysis of the gene encoding protease from Indonesian Stenotrophomonas sp. of food origin. The protease structure was predicted using bioinformatic tools. ${ }^{17}$ Structural comparison of this protease with similar protease reported earlier is expected to lead us to find best strategy and methods for furthur molecular experiment for increasing enzyme expression, productivity and furthur applications. This is the first report for analysis of protease gene from food origin Stenotrophomonas sp.

\section{Materials and methods}

\section{Chemicals and reagents}

All chemicals used in this study were analytical grade and purchased from Sigma (United States) and Oxoid (United Kingdom) through local distributors.

\section{Bacterial strains and plasmids}

Stenotrophomonas sp. isolate originated from Oncom was provided from Bogor Agricultural University, Indonesia. Vector pGEMT Easy (Promega, United States) was used for library construction in Escherichia coli DH5a (provided by Atmajaya University, Indonesia). Vector pET22b (Merck, United States) was used for gene expression in E. coli BL21 DE3 (Merck, United States).

\section{General recombinant DNA techniques}

All DNA manipulations described in this work were performed by standard methods. ${ }^{18}$ DNA isolation kit UltraClean ${ }^{\circledR}$ Microbial (MoBio, United States) was used for gDNA isolation. GoTaq Green MasterMix (Promega, United States) was used for Polymerase Chain Reaction (PCR). The PCR was performed in T3000-Thermal cycler (Biometra, Germany). Cloning DNA to pGEM-T Easy (Promega, United States), digestion of DNA with restriction endonuclease (Fermentas, United States), dephosphorylation with alkaline phosphatase (Fermentas, Unites States) and ligation with T4 DNA-ligase (Fermentas, United States) were performed in accordance to the manufacturer's instructions. Plasmids were purified using Miniprep method and DNA fragments were purified by Qiagen DNA purification kits (Qiagen, Germany).

\section{Cloning of protease gene}

The protease gene (annotated as Stenoprotease) was amplified using genomic DNA from Stenotrophomonas sp. as template for PCR. The reaction was performed in a $50 \mu \mathrm{L}$ volume with $4 \mu \mathrm{M}$ primer StenoF: 5'-CATATGTCCCAGGTAACGC-3' (forward) which has NdeI restriction site and StenoR: 5'-CTCGAGTACTGGGCGTTGA-3' (reverse) which has XhoI restriction site, $25 \mu \mathrm{L}$ of GoTaq Green Master Mix and 100 ngDNA template. DNA amplification was conducted based on the manufacture instruction. The PCR product was gel purified and ligated to pGEM-T Easy vector, yielding plasmid pGEM-T-Steno. The plasmid was transformed into E. coli $\mathrm{DH} 5 \alpha$ and the gene was sequenced using M13 primers pair. Plasmid pGEM-T-Steno that have protease gene was digested with $N d e \mathrm{I}$ and $\mathrm{XhoI}$ and ligated to pET22b, yielding plasmid pET22b-Steno. The construction of these plasmids can be seen on Figure 1. The plasmid was transformed into E. coli BL21 DE3 and used for expression.

\section{Expression of protease Steno in E. coli BL21 DE3}

For expression of protease Steno, the plasmid pET22b-Steno was freshly transformed into E. coli BL21 DE3 cells. These clones were

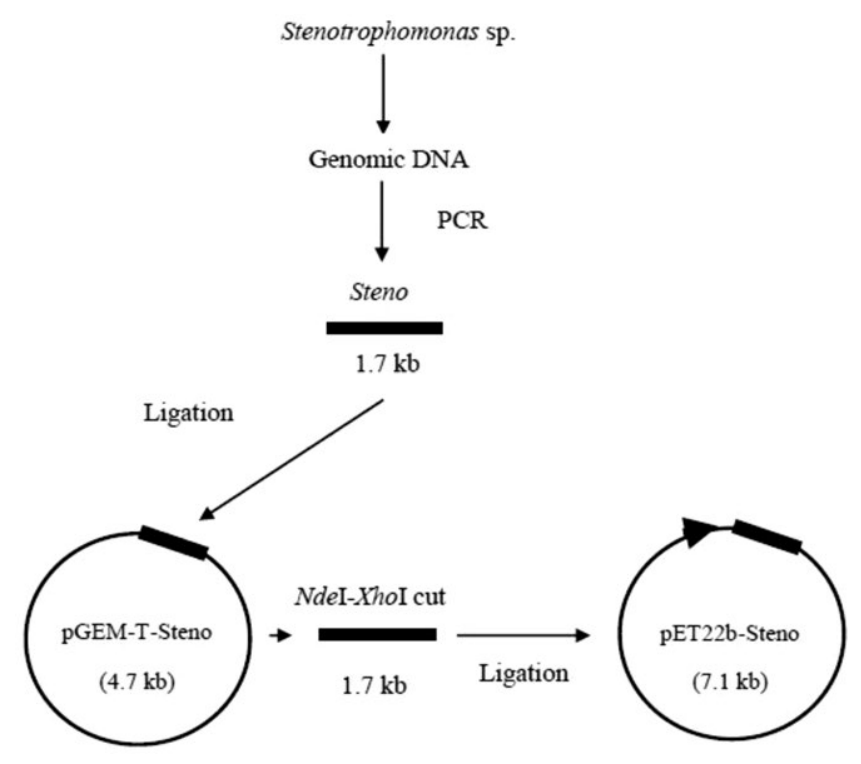

Figure 1. Construction of pGEM-T-Steno and pET22b-Steno recombinant plasmids containing protease gene from Indonesian Stenotrophomonas sp. 
then inoculated into $5 \mathrm{ml}$ Luria Bertani (LB) broth supplemented with $100 \mu \mathrm{g} / \mathrm{mL}$ ampicillin. The culture was grown overnight at $30^{\circ} \mathrm{C}$ on a rotary shaker at $150 \mathrm{rpm}$ and utilized to inoculate the main culture, composed of $100 \mathrm{ml}$ freshly prepared LB broth and $100 \mu \mathrm{g} / \mathrm{mL}$ ampicillin. The culture was incubated at $37^{\circ} \mathrm{C}$ and $150 \mathrm{rpm}$ until an optical density $(600 \mathrm{~nm})$ between $0.6-0.8$ was reached. The culture was then cooled down to $20^{\circ} \mathrm{C}$ and induced with IPTG at a final concentration of $0.05 \mathrm{mM}$. The induced culture was incubated at $20^{\circ} \mathrm{C}$ with shaking at $150 \mathrm{rpm}$ for approximately 6 hours. Cells were harvested by centrifugation at $5000 \mathrm{~g}$ and $4^{\circ} \mathrm{C}$ for 10 minutes. Cell pellet was resuspended in Phosphate Buffer Saline 1x and sonicated for 5 times with $20 \mathrm{~s}$ intervals. The suspension was centrifuged for 30 minutes at $13,000 \mathrm{rpm}$. The supernatant was collected as soluble fraction and the pellet was the insoluble fraction. These samples were run on SDS PAGE for protein molecular weight analysis.

\section{Agarose gel electrophoresis and SDS PAGE}

Agarose gel electrophoresis was carried out based on Sambrook et al.; ${ }^{18}$ PCR reagents (premixed with loading buffer) were loaded into $1 \%$ agarose gel (containing $0.5 \mu \mathrm{g} / \mathrm{mL}$ EtBr) and PCR was performed at $100 \mathrm{~V}$ and 45 minutes conditions. DNA was visualized on GelDoc ${ }^{\circledR}$ System (BioRad). SDS PAGE was carried out according to Laemmli; ${ }^{19}$ protein-containing samples were denatured with sample buffer $(43.5 \%$ glycerine, $2 \%$ SDS, 5\% merchaptoethanol, $0.1 \%$ bromphenol blue, $0.06 \mathrm{M}$ Tris Base $\mathrm{pH}$ 6.8) and run at $200 \mathrm{~V}$ for 40 minutes. Protein bands were stained with Coomassie Briliant Blue R250 and destained with destaining buffer (10\% methanol; $10 \%$ acetic glacial acid).

\section{DNA sequencing, database searches and alignments}

DNA was sequenced as custom service (1 1 stBASE). Analysis of DNA sequence was performed with Sequence Scanner v1.0, Serial Cloner v2.5, SignalP 4.1 (http://www.cbs.dtu.dk/services/SignalP/) and ExPASy translate tool (http://web.expasy.org/translate/). BLAST searches were performed using BLASTn and BLASTx software from National Center for Biotechnology Information (NCBI). Nucleotide sequences were aligned using the webserver Clustal Omega program (http://www.ebi.ac.uk/Tools/msa/clustalo/).

\section{Structural modeling of protease Steno}

3D structure of protease Steno was modeled using the program Modeler v9.1120 Amino acid sequence of protease Steno was firstly aligned to internal database on Modeller. Several proteases having lowest $\mathrm{E}$ value score were selected as templates for modelling the protease. The final templates were decided based on the highest homology, crystallographic resolution and crystallographic R factor.

\section{Deposition of sequence data}

The nucleotide sequence of protease Steno was deposited in the GenBank under accession number KJ440091.

\section{Results and discussion}

\section{Amplification and analysis of protease Steno}

The primers for PCR in this study were designed based on protease gene from Stenotrophomona smaltophilia. These primers generated 1749 bp PCR product. The gene sequence was analyzed using BLASTn and BLASTx. BLASTn revealed that the Stenoprotease gene showed 90\% homology with $\operatorname{Pr} 2$ gene from S. maltophilia and BLASTx revealed that the translated nucleotide showed high homol- ogy with minor extracellular protease $\mathrm{StmPr} 2$ preprotein, peptidase S8 and the secreted serine protease from S. maltophilia

Open reading frame of the gene (1740 bp) encodes a protein consisted of 580 amino acids with calculated mass of $58.3 \mathrm{KDa}$. Sequence alignment with homologous proteins revealed that the enzyme belongs to subfamily of subtilisin like serine proteases from S. maltophilia. The protein possess catalytic residue (black highlighted letter) similar to the protease from $S$. maltophilia and other serine protease (Figure 2). Based on the alignment with protein from S. maltophilia, we found the catalytic domain located between 177 until 409 residue followed with bacterial Pre-Peptidase C-terminal (PPC) domain until 577 residues. Active site residues of the Steno protease (Indonesian oncom) with aspartic acid on position 177, histidine on postion 237 and serine on position 409 pointed to the typical serine protease, such as subtilisin from Bacillus subtilis known as enzyme widely used for detergent, or fibrinolytic enzyme or natokinase from Bacillus subtilis. ${ }^{5,6,7}$ In fact serine protease family which include broader members such as digestive enzyme (trypsin, chymotrypsin, elastase), fibrinolytic enzyme of mammalian and bacterial origin (lumbrokinase, nattokinase) and various subtilisin type of enzyme secreted by Bacillus sp share the catalytic triad Asp-Histidine-Serine. Overall sequence analysis shows 94\% and 93\% similarity with peptidase and minor extracellular protease StmPr2 from Stenotrophomonas maltophilia known as an opportunistic bacteria which excretes protease with broad specificity. The alkaline serine enzyme is synthesized as $63-\mathrm{kDa}$ precursor which is processed to the mature protein of $47 \mathrm{kDa} .^{21}$

When comparing our protease Steno with the amino acid sequence of other protease originated from Bacillus subtilis, we found only $39 \%$ similarity to subtilisin (enzyme used in detergent). Interestingly, eventhough our enzyme was found as fibrinolytic (beside proteolytic), the sequence similarity of 39\% was found with nattokinase from Bacillus nato (fibrinolytic enzyme used as thrombolytic agent). In our previous study, the Stenotrophomonas sp. isolated from fermented food oncom was found as producers of strong fibrin and fibrinogen degrading enzymes. ${ }^{14,15}$

\section{D Modelling of protease gene}

Structure modelling of protease Steno of Indonesian Oncom was conducted using program Modeller 9.11. There are several proteases served as template for this modelling (residue 170-580). These proteases were subtilisin BPN from Bacillus amyloliquefaciens (PDB code 1to2), subtilisin Carlsberg from Bacillus licheniformis (PDB code 1r0r), serine protease subtilisin from Bacillus lentus (PDB code 1gci), subtilisin from Bacillus licheniformis (PDB code 1bh6), Proteinase K from Engyodontium album (PDB code 1ic6), AK.1 serine protease from Bacillus sp. AK1 (PDB code 1dbi), serine protease from Lysinibacillus sphaericus (PDB code 1ea7), mesenterico peptidase from Bacillus pumilus (PDB code 1mee), subtilisin like-serine protease from Fervidobacterium pennivorans (PDB code 1r6v), subtilisin BPN from Bacillus amyloliquefaciens (PDB code 1sbt), extracellular subtilisin-like serine protease from Vibrio sp. (PDB code 1sh7) and Thermitase from Thermoactinomyces vulgaris (PDB code 1 thm). The residues of these templates ranged between 269-671 amino acid residues, some of these templates were in the form of complex with its inhibitor (1to2, 1r0r, 1bh6, and 1mee). The sources of these templates were mostly from Bacillus genus (Table 1).

Serine protease subtilisin from Bacillus lentus (PDB code 1gci) was selected as template because of better sequence homology (52.26\%), better crystallographic resolution $(0.8 \AA)$ and better crystallographic R-factor $(9.9 \%)$. Modelling of protease Steno on Bacillus lentus subtilisin (Figure 3A) revealed that the alpha helical and beta sheet domain appeared structurally similar. In comparison to the subtilisin from Bacillus lentus (Figure 3B), ${ }^{22}$ the beta sheet in pro- 
tease Steno appeared to be less accessible (more buried). The protruded random coil chain (indicated by arrow) might be the unprocessed amino acids making up the PPC domain. In silico analysis using SignalP, ${ }^{23}$ showed that protease Steno possess a signal peptide which is cleaved most likely between Ala32 and Gly33 upon excretion. This finding might indicate that the protein is expressed as precursor molecule. Amino acid alignment with subtilisin from Bacillus lentus confirmed the presence of the typical catalytic triad of the serine protease family: histidine, serine and aspartic acid (red letter) (Figure 3C), even though at different positions.

\section{Cloning and expression of protease gene}

The Steno protease gene was then subcloned into pET22b with E. coli $\mathrm{BL} 21 \mathrm{DE} 3$ as the host. The expressed protein was expected to have larger size due to addition of HisTag on its $\mathrm{C}$ terminal. The size was approximately $59.4 \mathrm{KDa}$ (Figure 4) in agreement with the expected protein size based on the previous gene sequence analysis, which revealed open reading frame of $1740 \mathrm{bp}$ encoding a protein of 580 amino acids with calculated mass of $58.3 \mathrm{KDa}$. Figure 4 showed that the expressed protein was only observed in the total cellular pro- tein and insoluble fraction. This result indicated that the protein was expressed as aggregate (inclusion bodies) form. This might indicate insufficient post translational processing in the E. coli host. ${ }^{24}$ The protease excreted from $S$ maltophilla which share sequence similarity with our protease was reported as about $47 \mathrm{kD}$ mature protein. Even though this protease and our protease belong to serine protease, the molecular weight are somewhat larger than the protease of subtilisin family.

\section{Conclusions}

We have succeeded in cloning and analysis of protease Steno from Stenotrophomonas sp. originated from Oncom, a fermented Indonesian food. This is the first report on protease gene analysis from Stenotrophomonas of food origin. Protein modelling and sequence analysis revealed that the protease was a serine protease with typical catalytic triad (Asp, His, Ser) and expressed as an immature protein, mostly as inclusion bodies.

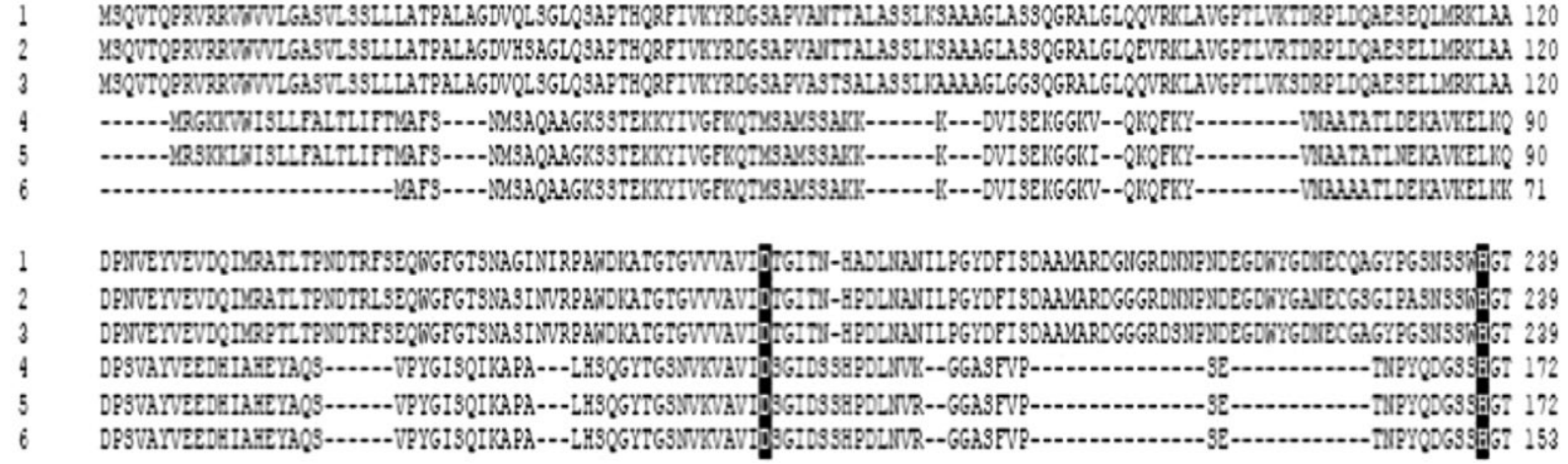

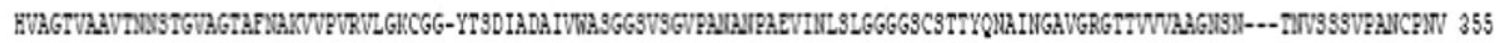

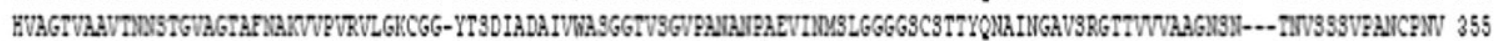

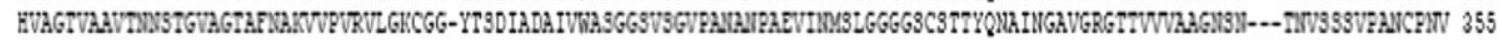

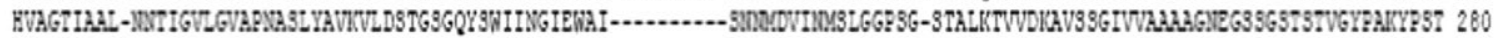

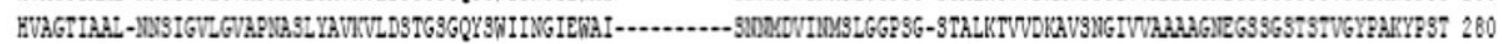

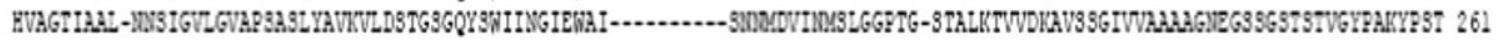

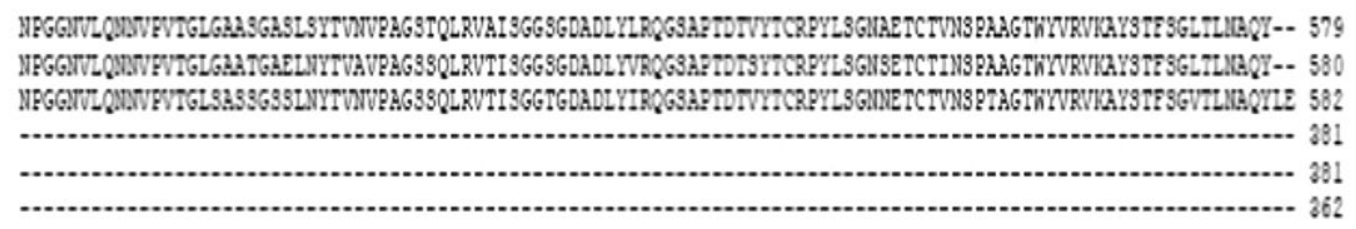

Figure 2. Sequence alignment of protease from Indonesian Stenotrophomonas sp with several homologous protein. Catalytic triad is indicated by black highlighted letter. The proteases used for sequence alignment were: (1) peptidase $\mathbf{S 8}$ from Stenotrophomonas maltophilia, (2) minor extracellular protease StmPr2 (3) our protease (Steno), (4) subtilisin from Bacillus subtilis, (5) fibrinolytic enzyme F1 from Bacillus subtilis, and (6) nattokinase from Bacillus subtilis. 

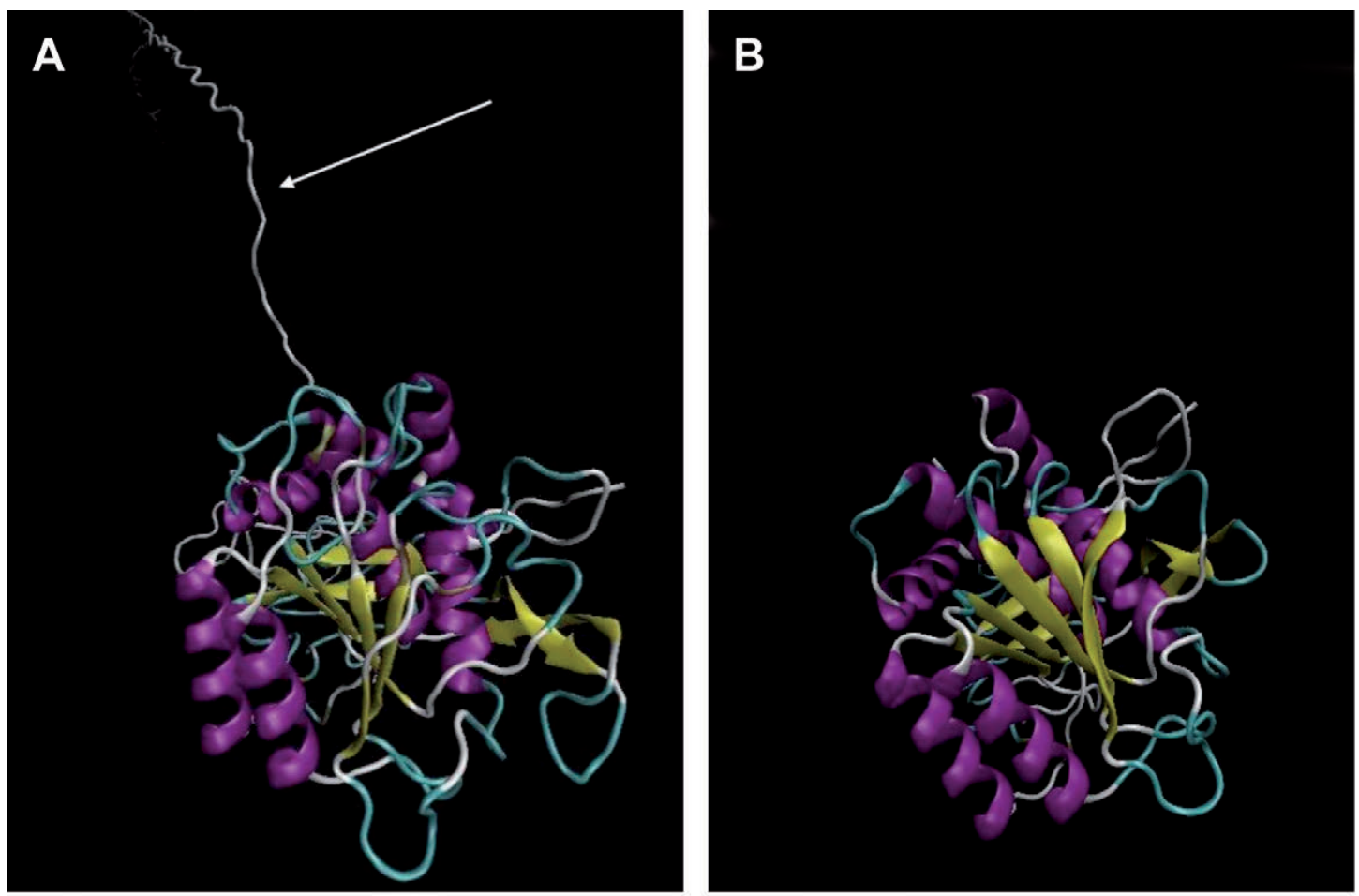

\section{C}

Subtilisin Protease

Subtilisin Protease

Subtilisin Protease

Subtilisin Protease

Subtilisin Protease

Subtilisin Protease

Subtilisin Protease

Subtilisin Protease

Subtilisin Protease

Subtilisin Protease
MSQVIQPRVRRVWVULGASVLSSLLIATPALAGDVQISGLQSAPTHQREIVKYRDGSAPV ASTSALASSLRAAAAGLGGSQGRALGLQQVRKLAVGPTLVKSDRPLDQAESELIMRIAA -AQSVPWGISRVQAPAA---HNRGLTGSGVKVAVLDTGI DPNVEYVEVDQIMRPTLTPNDTRESEQWGEGISNASINVRDAWDKATGTGVVVAVIDTGI

STHPDLNIR--GGASEVPGEPSTQD-1TNHPDINANILPGYDEISDAAMARDGGGRDSNPNDEGDWYGDNECGAGYPGSNSSWHGTH

VAGTIAAL-NNSI GVLGVAPSAELYAVKVIGASGSGSVSSIAQGLEWAGNNGM-----VAGTVRAVTNNSTGVAGTAENAKVVPVRVLGKCG-GYTSDIADAIVWASGGSVSGVPANA

---HVANLSLGSP-SPSATLEQAVNSATSRGVLVVAASGNSGA-GSISYPARYANAMAVG NPAEVINMSLGGGGSCSTTYQNAINGAVGRGTTVVVAAGNSNTNVSS SVPANCPNVIAVA.

ATDQNMNRASESQYGAGLDIVAPGVNVQSTYP-------GSTYASINGTSMATPHVAGAA ATISAGARASFSNYGTGIDISADGQSIISTLNSGTTTDGSASYASYNGTSMAADHVAGVV

ALVKQKNPSWS-NVQIRNHLKNTATSLGST--NLYGSGLVNAEAATR------ - - - ALMQSVAPSPISPAQVESIIKSTARPIPGSCSGGCGAGIIDADAAVSAAINGGGIPNPGG

NVLONNVPVTGLSASSGSSINYTVNVPAGSSQLRVIISGGTGDADIYIRQGSAPTDTVYT

CRPYLSGNVICTVNSPTAGTWYVRVKAYSTESGVTLNAQYLE

Figure 3. Modelled structure of protease Steno (A) with the protruded peptide chain (indicated by arrow); structure of the serine protease subtilisin from Bacillus lentus $(\mathrm{B})$ and amino acid alignment $(\mathrm{C})$ between protease Steno from Stenotrophomonas sp. and subtilisin from Bacillus lentus (active site indicated by red letter). 
Table 1. Proteases served as template for modelling protease Steno.

\begin{tabular}{|c|c|c|c|c|}
\hline Protein code & Protein name & Source microorganism & Description & Residue \\
\hline 1 to2 & Subtilisin BPN & Bacillus amyloliquefaciens & $\begin{array}{l}\text { Crystal structure of the complex of subtilisin BPN' with } \\
\text { chymotrypsin inhibitor } 2 \text { M59K, in pH } 9 \text { cryosoak }\end{array}$ & $\begin{array}{l}\text { Chain E: } 281 \text { residue } \\
\text { Chain I: } 64 \text { residue }\end{array}$ \\
\hline $1 \mathrm{r} 0 \mathrm{r}$ & Subtilisin Carlsberg & Bacillus licheniformis & $\begin{array}{l}\text { 1.1 Angstrom Resolution Structure of the Complex } \\
\text { Between the Protein Inhibitor, OMTKY3, and the Serine } \\
\text { Protease, Subtilisin Carlsberg }\end{array}$ & $\begin{array}{l}\text { Chain E: } 274 \text { residue } \\
\text { Chain I: } 51 \text { residue }\end{array}$ \\
\hline lgci & $\begin{array}{l}\text { Serine protease } \\
\text { subtilisin }\end{array}$ & Bacillus lentus & $\begin{array}{l}0.78 \text { Angstroms Structture of a Serine Protease-Bacillus } \\
\text { Lentus Subtilisin }\end{array}$ & Chain A: 269 residue \\
\hline lbh6 & Subtilisin & Bacillus licheniformis & $\begin{array}{l}\text { Subtilisin DY in Complex with the Synthetic Inhibitor } \\
\text { N-Benzyloxycarbonyl-Ala-Pro-Phe-Chloromethyl Ketone }\end{array}$ & Chain A: 274 residue \\
\hline lic6 & Proteinase $\mathrm{K}$ & Engyodontium album & $\begin{array}{l}\text { Structure of A Serine Protease Proteinase K from } \\
\text { Tritirachium Album Limber at } 0.98 \text { A resolution }\end{array}$ & Chain A: 279 residue \\
\hline $1 \mathrm{dbi}$ & AK.1 serine protease & Bacillus sp. AK1 & Crystal Structure of A Thermostable Serine Protease & Chain A: 280 residue \\
\hline lea7 & Serine protease & Lysinibacillus sphaericus & $\begin{array}{l}\text { The 0.93A Crystal Structure of Sphericase: A Calcium- } \\
\text { Loaded Serine Protease from Bacillus Sphaericus }\end{array}$ & Chain $\mathrm{A}: 310$ residue \\
\hline 1mee & $\begin{array}{l}\text { Mesenterico } \\
\text { peptidase }\end{array}$ & Bacillus pumilus & $\begin{array}{l}\text { Complex between the subtilisin from a mesophilic } \\
\text { bacterium and the leech inhibitor eglin-C }\end{array}$ & Chain A: 275 residue \\
\hline $1 \mathrm{r} 6 \mathrm{v}$ & $\begin{array}{l}\text { Subtilisin } \\
\text { like-serine protease }\end{array}$ & $\begin{array}{l}\text { Fervidobacterium } \\
\text { pennivorans }\end{array}$ & $\begin{array}{l}\text { Crystal structure of fervidolysin from Fervidobacterium } \\
\text { pennivorans, a keratinolytic enzyme related to subtilisin }\end{array}$ & Chain A: 671 residue \\
\hline $1 \operatorname{sh} 7$ & $\begin{array}{l}\text { Extracellular } \\
\text { subtilisin-like } \\
\text { serine protease }\end{array}$ & Vibrio sp. & $\begin{array}{l}\text { Crystal structure of a subtilisin-like serine proteinase } \\
\text { from a psychrotrophic Vibrio species }\end{array}$ & Chain A,B: 284 residue \\
\hline 1thm & Thermitase & Thermoactinomyces vulgaris & Crystal structure of thermitase at 1.4 A resolution & Chain A: 279 residue \\
\hline
\end{tabular}

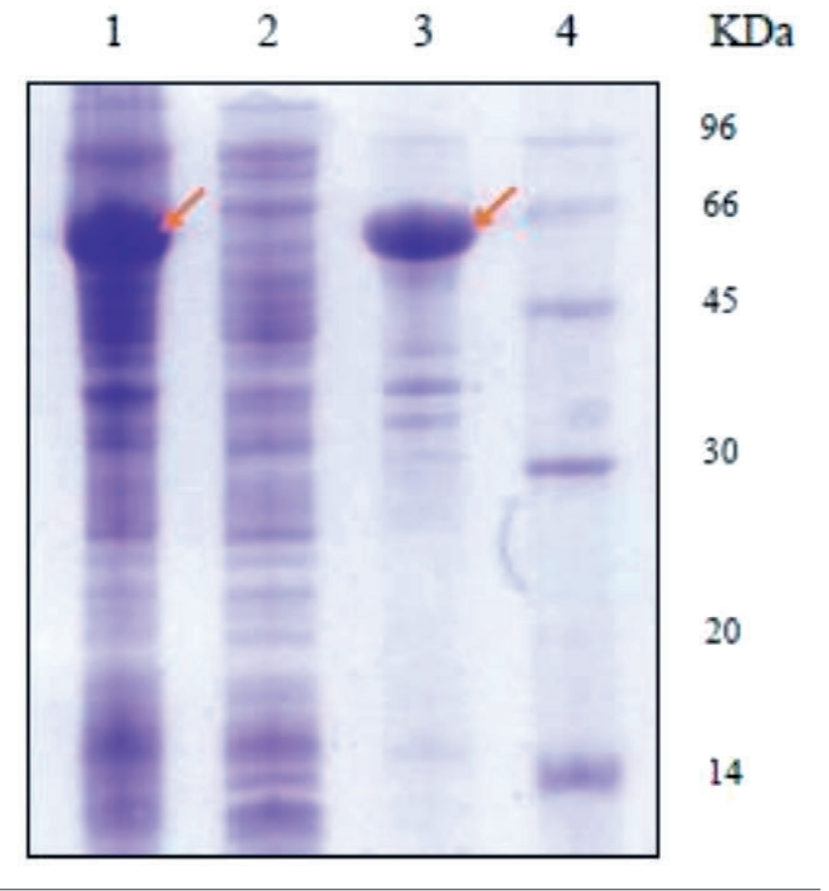

Figure 4. SDS PAGE of expressed protein from BL21 pET22bSteno. Lane 1: Total cellular protein; Lane 2: Soluble fraction, Lane 3: Insoluble fraction; Lane 4: Low Molecular Weight Marker (GE Healthcare). Expected protein target is shown by the red arrow.

\section{References}

1. Ryan RP, Monchy S, Cardinale M, et al. The versatility and adaptation of bacteria from genus Stenotrophomonas. Nat Rev Microbiol 2009;7:514-25.

2. Berg G, Roskot N, Smalla K, et al. Genotypic and phenotypic relationships between clinical and environmental isolates of Stenotrophomonas maltophilia. J Clin Biol 1999;37:3594600.

3. Huang X, Liu J, Ding J, et al. The investigation of nematodical activity in Stenotrophomonas maltophilia G2 and characterization of a novel virulence serine protease. Can J Microbiol 2009;55:934-42.

4. Rao MB, Aparna MT, Mohini SG, Deshpande VV. Molecular and biotechnological aspects of microbial proteases. Microbiol Mol Biol R 1998;63:597-635.

5. Kumar CG, Takagi H. Microbial alkaline proteases: from a bioindustrial viewpoint. Biotechnol Adv 1999;17:561-94.

6. Gupta R, Beg QK, Lorenz P. Bacterial alkaline proteases: molecular approaches and industrial applications. Appl Microbiol Bio Rev 2002;59:15-32.

7. Hua Y, Jiang B, Mine Y, Mu W. Purification and characterization of a novel fibrinolytic enzyme from Bacillus sp. nov. SK006 isolated from an Asian traditional fermented shrimp paste. J Agr Food Chem 2008;56:1451-7.

8. Chang AK, Kim HY, Park JE, et al. Vibrio vulnificus secretes a broad-specificity metalloprotease capable of interfering with 
blood homeostasis through prothrombin activation and fibrinolysis. J Bacteriol 2005;187:6909-16.

9. Simkhada JR, Mander P, Cho SS, Yoo JC. A novel fibrinolytic protease from Streptomyces sp. CS684. Process Biochem 2010;45:88-93.

10. Ribitsch D, Heumann S, Karl W, et al. Extracellular serine proteases from Stenotrophomonas maltophilia: screening, isolation and heterologous expression in E. coli. J Biotech 2012;157:140-7.

11. Kuddus M, Ramteke PW. Cold-active extracellular alkaline protease from an alkaliphilic Stenotrophomonas maltophilia: production of enzyme and its industrial applications. Can J Microbiol 2009;11:1294-301.

12. Kim W, Choi K, Kim Y, et al. Purification and characterization of a fibrinolytic enzyme produced from Bacillus sp. strain CK 11-4 screened from Chungkook-Jang. Appl Environ Microbiol 1996;62:2482-8.

13. Uesugi Y, Usuki H, Iwabuchi M, Hatanaka T. Highly potent fibrinolytic serine protease from Streptomyces. Enzyme Microb Tech 2011;48:7-12.

14. Stephani L, Tjandrawinata RR, Afifah DN, et al. Food origin fibrinolytic enzyme with multiple actions. Hayati, J. Bioscie. 2017, submitted.

15. Nailufar F, Tjandrawinata RR, Suhartono MT, et al. Thrombus degradation by fibrinolytic enzyme of Stenotrophomonas sp. originated from Indonesian soy bean-based fermented food on wistar rats. Adv Pharmacol Sci 2016;2016:1-9.

16. Ribitsch D, Karl W, Gruenberger RB, et al. C-terminal trunca- tion of a metagenome-derived detergent protease for effective expression in E. coli. J Biotechnol 2010;150:408-16.

17. Breda A, Valadares NF, Norberto de Souza O, et al. Protein structure, modelling and applications. In: Gruber A, Durham AM, Huynh C, et al., eds. Bioinformatics in tropical disease research: a practical and case-study approach. Bethesda: National Center for Biotechnology Information; 2008.

18. Sambrook J, Fritsch EF, Maniatis T. Molecular cloning: a laboratory manual. 2nd ed. New York: Cold Spring Harbor Laboratory Press; 1989.

19. Laemmli UK. Cleavage of structural proteins during the assembly of the head of bacteriophage T4. Nature 1970;227:680-5.

20. Eswar N, Eramian D, Webb B, et al. Protein structure modeling with MODELLER. In: Kobe B, Guss M, Huber T, eds. Methods Mol. Biol, New York: Humana Press; 2008. pp 145-159.

21. Windhorst S, Frank E, Georgieva DN, et al. The major extracellular protease of the nosocomial pathogen Stenotrophomonas maltophilia. J Biol Chem 2002;277:11042-9.

22. Khun P, Knapp M, Soltis SM, et al. The 0.78 A structure of a serine protease: Bacillus lentus subtilisin. J Biochem 1998;37:13446-52.

23. Bendsten JD, Nielsen H, von Heijne G, Brunak S. Improved prediction of signal peptides-SignalP 3.0. J Mol Biol 2004;340:783-95.

24. Wieland S, Maurer KH, Kottwitz B, et al. Novel alkaline protease from soil microorganism and washing and cleaning products containing the novel enzyme. 2005; PCT Int Appl WO 2005063974 A1 20050714. 